\title{
Kwaliteit van de financiële verslaggeving in Nederland
}

Prof. Dr. M.N. Hoogendoorn en Prof. Dr. G.M.H. Mertens

\section{Inleiding}

In 1999 publiceerde Traas een tweedelige artikelenserie, getiteld 'Om de kwaliteit van de Nederlandse jaarverslaggeving'. De algemene stelling van Traas is dat Nederland ver achterblijft bij de internationale 'best practice'. Hij haalt daarbij tevens de jury van de Henri-Sijthoffprijs aan (waarvan hij zelf deel uitmaakt), die stelt dat bij veel ondernemingen al een aantal jaren sprake is van 'een gezapig voortkabbelen van de verslaggeving op het niveau van een kleine zes'. Dit betreft zowel de jaarrekening als het jaarverslag (verslag van de Raad van Bestuur). Traas treedt hiermee in de voetsporen van eerdere discussies over de kwaliteit van de financiële verslaggeving in Nederland, zoals die zijn gevoerd door onder andere Zeff, Van der Wel en Camfermann (1992), Volten (1992) en Heijnen (1996).

Ook in bijvoorbeeld de Verenigde Staten zijn discussies over de kwaliteit van de financiële verslaggeving actueel. Vooral Arthur Levitt heeft tijdens zijn voorzitterschap van de SEC de winstbeïnvloeding ('earnings management', 'hocuspocus-accounting') aan de kaak gesteld en aangegeven dat dit aan de kwaliteit van de verslaggeving in ernstige mate afbreuk doet ${ }^{1}$.

Hij noemt in dat verband onder andere:

- het nemen van diverse grote lasten in één keer ('big bath'), zodat ruimte ontstaat voor toekomstige winstverbeteringen;

- het gebruikmaken van voorzieningen: het

Prof. Dr. M.N. Hoogendoorn is hoogleraar Externe Verslaggeving aan de Universiteit van Amsterdam, partner bij Ernst \& Young Accountants en lid van de Raad voor de Jaarverslaggeving.

Prof. Dr. G.M.H. Mertens is verbonden aan de Universiteit Nyenrode/NIB Capital.

De auteurs danken Drs. M. Pronk voor zijn opmerkingen bij een concept van dit artikel. opbouwen daarvan in goede jaren en het daarvan afboeken of laten vrijvallen in slechte jaren, waardoor een meer egaal resultaat ontstaat (winstegalisatie, 'income smoothing');

- het bewustmaken van fouten die vanuit een bepaalde optiek als 'niet materieel' kunnen worden beschouwd maar toch bijdragen aan winststuring;

- het als omzet boeken van een nog niet volledig afgeronde verkooptransactie (bijvoorbeeld uit hoofde van meeverkochte servicecontracten, waarbij de service nog geleverd moet worden).

Sinds de publicatie van het zogenaamde Blue Ribbon rapport ${ }^{2}$ in 1999 lijkt voorts de term 'quality of financial reporting' in de Verenigde Staten een ingeburgerd begrip te worden (Jonas and Blanchet, 2000). Ook in het Verenigd Koninkrijk zijn in de jaren negentig verschillende boeken verschenen over het probleem van 'creative accounting' (zie onder andere Smith, 1992).

Kortom, het vraagstuk van de kwaliteit van de financiële verslaggeving staat in Nederland en in het buitenland volop in de belangstelling. Dit nog afgezien van alle achterliggende ontwikkelingen in het kader van de internationale harmonisatie van de regelgeving (toepassing van International Accounting Standards), waarmee expliciet een verbetering van de kwaliteit van de financiële verslaggeving is beoogd.

In Nederland is de afgelopen jaren een uitgebreid onderzoek verricht naar de kwaliteit van de financiële verslaggeving. De aanleiding hiervoor vormde mede de hierboven vermelde kritische opmerkingen over de kwaliteit van externe financiële verslaggeving in Nederland, echter zonder dat hiervoor systematisch bewijsmateriaal was verzameld. Dit onderzoek had tot doel dit materiaal te verzamelen en te analyseren om zodoende een meer gefundeerd oordeel over de kwaliteit van externe financiële verslaggeving te kunnen geven. 
Aan het onderzoek heeft een groot aantal onderzoekers een bijdrage geleverd ${ }^{3}$. Het onderzoek is gestart in 1996, onder regie van het Limperg Instituut, en in 2000 afgerond. De belangrijkste resultaten van dit onderzoek zijn gepresenteerd op het Symposium Kwaliteit Financiële Verslaggeving van 23 november 2000, gehouden op de Universiteit van Amsterdam. Ter gelegenheid daarvan is bij het Limperg Instituut een brochure verschenen. Voorts verschijnt in de tweede helft van dit jaar het definitieve eindrapport.

In dit artikel geven wij een overzicht van dit onderzoek. Uiteraard kan de beschrijving in het kader van dit artikel slechts beknopt zijn. Een specifiek aspect van het project, het onderzoek bij financiële analisten, wordt in dit themanummer in het artikel van Blij beschreven. Voorts gaat Vergoossen in zijn artikel in op een ander element van het project, het toezicht op de financiële verslaggeving. Het onderzoek is uitgemond in een twintigtal aanbevelingen, die wij in een bijlage hebben opgenomen.

De indeling van dit artikel is verder als volgt:

- In paragraaf 2 gaan wij in op de probleemstelling en de reikwijdte van het onderzoek.

- In paragraaf 3 behandelen wij de vaststelling van kwaliteitscriteria.

- In paragraaf 4 komen de empirische resultaten naar voren.

- In paragraaf 5 zijn de conclusies opgenomen.

\section{Probleemstelling en reikwijdte onderzoek}

\subsection{Inleiding: het belang van kwalitatief goede verslaggeving}

De kernvragen van dit onderzoek zijn: wat is en wat bepaalt de kwaliteit van financiële verslaggeving? In het eindrapport wordt hierop uitgebreid ingegaan. In algemene zin kan worden gesteld dat kwaliteit van financiële verslaggeving in essentie samenhangt met de stakeholders waarop de financiële verslaggeving is gericht. Het gaat erom dat de stakeholders zich op basis van de financiële verslaggeving een goed oordeel kunnen vormen over de financiële resultaten en financiële positie van de onderneming. Men kan zeggen: hoe beter zij zich een oordeel kunnen vormen, des te hoger is de kwaliteit van de verslaggeving.

Als we ons beperken tot de aandeelhouders en vreemdvermogenverschaffers als stakeholders, dan is een goede beoordeling van de financiële resultaten en positie van belang voor onder andere:

- de beslissing om aandelen te kopen, te houden, of te verkopen;

- de beslissing om wel of niet in te schrijven op een ter beurze geïntroduceerd aandeel;

- de beslissing om bij een overname de aandelen wel of niet aan te bieden tegen de voorgestelde prijs;

- de beslissing om het bestuur wel of niet décharge te verlenen voor het gevoerde beleid;

- de beslissing om wel of niet in te schrijven op een (converteerbare) obligatielening;

- de beslissing om wel of niet krediet te verlenen en zo ja, tegen welke kredietvoorwaarden (rentepercentage, terugbetalingsverplichtingen, zekerheidsstelling).

Kortom, een juiste beoordeling door stakeholders is van belang voor de goede werking van de financiële markten. Dit speelt vooral bij stakeholders die op enige afstand van de onderneming staan, zoals bij beursgenoteerde ondernemingen.

\subsection{Probleemstelling}

De centrale probleemstelling van het onderzoek is als volgt geformuleerd:

Wat is de kwaliteit van de externe financiële verslaggeving in Nederland en hoe kan die kwaliteit worden verbeterd?

Kwaliteit omschrijven wij in algemene zin als 'voldoen aan eisen en verwachtingen'. Daarom is kwaliteit gerelateerd aan de doelstelling van financiële verslaggeving, gericht op het voorzien in de informatiebehoeften van stakeholders.

De probleemstelling is gericht op het meten van de kwaliteit van financiële verslaggeving. Daarvoor zijn criteria nodig, die in het kader van dit onderzoek zijn ontwikkeld. Een met kwaliteit samenhangend begrip is transparantie. In het kader van dit onderzoek zijn beide begrippen aan elkaar gelijkgesteld. Een kwalitatief goede verslaggeving is een verslaggeving die transparant is naar de stakeholders. Door de betere transparantie zijn stakeholders beter in staat adequate afwegingen te maken tussen risico's en rendementen, waardoor de optimale werking van de kapitaalmarkt wordt bevorderd.

\subsection{Reikwijdte onderzoek}

In dit onderzoek hebben wij ons primair gericht op de jaarrekening. Daarnaast is aandacht besteed aan het jaarverslag (het verslag van de Raad van Bestuur) en aan tussentijdse berichtgeving. Jaarverslag en jaarrekening zullen wij hierna gezamenlijk aanduiden met de term financieel verslag. Wij zijn daarbij uitgegaan van de papieren versies van de berichtgeving, wetende dat de 
berichtgeving via internet op dit moment nog niet veel verder is dan het elektronisch beschikbaar stellen van deze papieren versies.

Het onderzoeksproject is verdeeld in een drietal hoofdfasen:

I: Inventariseren van criteria voor kwaliteit (zie paragraaf 3).

II: Onderzoek onder analisten (zie paragraaf 4.1 en 4.2).

III: Onderzoek van financiële verslagen (zie paragraaf 4.3).

Het onderzoek van financiële verslagen heeft uitsluitend plaatsgevonden bij beursgenoteerde ondernemingen.

\section{Inventarisatie kwaliteitscriteria}

\subsection{Dimensies van kwaliteit}

In dit onderzoek onderscheiden we twee dimensies van kwaliteit, namelijk de inhoud van financiële verslaggeving en de infrastructuur rondom de financiële verslaggeving. De belangrijkste dimensie van kwaliteit van financiële verslaggeving betreft de inhoud van de financiële verslaggeving. Aspecten daarbij zijn:

- informatie-elementen in het financiële verslag ('disclosure');

- toegepaste grondslagen van waardering en resultaatbepaling;

- de wijze van presentatie van informatie;

- de frequentie en tijdigheid van presentatie van informatie.

Daarnaast is ook de kwaliteit van de infrastructuur rondom de financiële verslaggeving van belang. Aspecten daarvan zijn:

- de structuur van wet- en regelgeving inzake financiële verslaggeving;

- de mate van flexibiliteit die ondernemingsleidingen hebben inzake het bepalen van vermogen en resultaat;

- de mechanismen tot handhaving van de kwaliteit;

- de kwaliteit van financiële analyse.

In het eindrapport wordt op deze elementen uitgebreid ingegaan. In dit artikel richten we ons vooral op de informatie-elementen, de grondslagen van waardering en resultaatbepaling en de mechanismen tot handhaving van kwaliteit.

\subsection{Kwaliteitscriteria inzake informatie-elementen}

De eerste fase van ons onderzoek betrof het opstellen van een voorlopige set van kwaliteits- criteria. De kwaliteitscriteria zijn ontwikkeld op basis van een aantal bronnen, te weten:

- nationale en internationale wet- en regelgeving;

- internationale studierapporten;

- criteria voor verslaggevingsprijzen.

De onderzochte nationale en internationale wet- en regelgeving zijn:

- Nederland:

-Burgerlijk Wetboek, deel 2, Titel 9;

-Richtlijnen voor de Jaarverslaggeving.

- Europese Unie:

-Vierde Richtlijn;

-Zevende Richtlijn.

- International Accounting Standards Committee: -International Accounting Standards (IAS).

- Verenigde Staten (US GAAP).

- Verenigd Koninkrijk (UK GAAP).

Als uiteindelijke basis voor het samenstellen van de totaalset van kwaliteitscriteria is de wet- en regelgeving per 1 januari 1998 gekozen. De set van kwaliteitscriteria werd nog eenmaal geactualiseerd per 31 december 1998 voor wat betreft de IAS.

De bestudeerde internationale studierapporten zijn:

- The Corporate Report (Institute of Chartered Accountants in England and Wales, 1975).

- Making Corporate Reports Valuable (The Institute of Chartered Accountants of Scotland, 1988.

- The Future Shape of Financial Reports (The Institute of Chartered Accountants in England and Wales and The Institute of Chartered Accountants of Scotland, 1991).

- Improving Business Reporting - a customer focus; meeting the information needs of investors \& creditors ('Jenkins Report') (American Institute of Certified Public Accountants, 1994.

- Information to be Included in the Annual Report to Shareholders (The Canadian Institute of Chartered Accountants, 1991).

- International Accounting and Auditing Trends (Center for International Financial Analysis \& Research (CIFAR), 1989).

$\mathrm{Na} 1994$ zijn geen toonaangevende rapporten meer verschenen. In het eindrapport wordt op deze studierapporten nader ingegaan.

Ten slotte zijn de volgende prijzen in het kader van deze studie geanalyseerd:

- The Annual Report Awards (Australië).

- Annual Report Awards (Canada).

- Henri Sijthoffprijs (Nederland).

- The Annual Report Award (Nieuw Zeeland).

- Award for Excellence in Corporate Reporting (Verenigde Staten). 
- Merkurpreis (Zwitserland).

- Prijs voor de beste financiële informatie

(European Federation of Financial Analysts).

Ook op het karakter van deze verslaggevingsprijzen wordt in het eindrapport uitgebreid ingegaan.

Uit de drie hierboven besproken bronnen is uiteindelijk één totaallijst met voorlopige kwaliteitscriteria inzake informatie-elementen afgeleid. Het totaal aantal informatie-elementen op deze totaallijst bedraagt 1812. Hiervan hebben 1380 informatie-elementen betrekking op de jaarrekening en 432 informatie-elementen op het jaarverslag. Deze lijst is het uitgangspunt geweest voor het empirisch onderzoek onder analisten.

\subsection{Kwaliteitscriteria inzake toegepaste grond- slagen van waardering en resultaatbepaling}

Wij hebben een inventarisatie uitgevoerd van alle herkenbare opties in de Nederlandse wet- en regelgeving per 1 januari 1998. Dit geeft een indicatie van de bestaande flexibiliteit. In het analistenonderzoek is vastgesteld in hoeverre voor bepaalde grondslagen in Nederland een voorkeur bestaat of niet.

Wij hebben in totaal 37 transacties en gebeurtenissen vastgesteld waaromtrent twee of meer alternatieve mogelijkheden van verwerking in de balans en winst- en verliesrekening bestaan. Het totaal aantal opties komt uit op 81. Indien voor een onderneming alle 37 transacties en gebeurtenissen relevant zijn, kan worden berekend dat er 2348 miljard (!) verschillende alternatieve grondslagen van waardering en resultaatbepaling zijn. Uiteraard moet dit getal niet al te absoluut worden genomen. Verschillende alternatieven kunnen bijvoorbeeld op ongeveer dezelfde winst- en vermogenscijfers uitkomen. Bovendien zijn mogelijk niet alle alternatieven onafhankelijk van elkaar te kiezen. Aan de andere kant zijn er nog veel meer alternatieven, namelijk die inzake gebeurtenissen en transacties die niet in de regelgeving zijn behandeld. Wat wel duidelijk is, is dat het aantal alternatieven zo groot is dat een grote mate van flexibiliteit aanwezig is.

In het eindrapport wordt uitgebreid op de alternatieven ingegaan. Een aantal alternatieven komt in 4.2 aan de orde.

\subsection{Mechanismen tot handhaving van de kwaliteit}

In deze subparagraaf gaan wij in op de handhaving van de kwaliteit van financiële verslaggeving in de institutionele context. Wij behandelen niet de eerstelijnshandhaving door middel van accountantscontrole, maar richten ons op de tweede lijn.
Bij deze tweede lijn passen correctieve of sanctiemaatregelen indien de kwaliteit onvoldoende is. In algemene zin betekent dit dat niet voldaan is aan het in de Nederlandse wet- en regelgeving opgenomen allesoverheersende basisvoorschrift, namelijk dat de jaarrekening een zodanig inzicht geeft dat door stakeholders een verantwoord oordeel kan worden gevormd.

Het institutionele kader waarbinnen kwaliteitshandhaving plaatsvindt, de reikwijdte, en de wijze waarop dit getracht wordt te bereiken, verschillen per land. In Nederland geldt dat de handhaving van de wettelijke voorschriften sinds 1971 in handen is van de Ondernemingskamer (OK). Deze situatie is in vergelijking tot de meeste andere landen uniek.

In het kader van ons onderzoek naar de kwaliteit van externe financiële verslaggeving hebben wij stilgestaan bij de vraag hoe functioneel en effectief het thans geldende systeem is. Dit is in eerste instantie gedaan door de situatie in Nederland te beschrijven en tevens een vergelijking te maken met de situatie in andere landen. Daarbij zijn naast Nederland een drietal andere landen onderzocht, te weten het Verenigd Koninkrijk, de Verenigde Staten en Australië. In deze vergelijkende studie is onder meer gekeken naar de ontstaansgeschiedenis van wet- en regelgeving en de hieruit voortgekomen nationale mechanismen voor handhaving van de kwaliteit. Tevens zijn de posities van de verschillende instanties respectievelijk organen apart bestudeerd evenals de aanwezige sanctiemaatregelen. De bevindingen die uit deze vergelijkende studie naar voren zijn gekomen worden weergegeven in ons eindrapport.

Wij concluderen dat, in vergelijking met de andere instanties, de OK minder toegankelijk is, niet actief optreedt en zich beperkt tot de expliciet vermelde klachten in de dagvaarding.

Een sterk handhavingsmechanisme is voor de kwaliteit van de financiële verslaggeving van groot belang. Op deze wijze kan worden bewerkstelligd dat ondernemingen niet ongestraft afwijken van de geldende wet- en regelgeving. Een goed handhavingsmechanisme is bij voorkeur proactief (reagerend op maatschappelijke signalen en klachten), laagdrempelig (geen beperkt belanghebbendebegrip) en gezaghebbend. De OK is zonder twijfel gezaghebbend, maar voldoet niet aan de eisen van pro-actief en laagdrempelig. Om die reden zijn wij van mening dat het wenselijk is een orgaan op te zetten dat specifiek belast is met het toezicht op de financiële verslaggeving. Het Financial Reporting Review Panel, zoals dat functioneert in het Verenigd Koninkrijk, kan hierbij als 
voorbeeld dienen. Dit panel is laagdrempelig en reactief. Een stap verder kan zijn door het toezichtsorgaan ook zelf actief te laten optreden. Of dit een specifiek Nederlands orgaan moet zijn, is hierbij de vraag. De actieve pogingen in Europees verband om verdere harmonisatie te bewerkstelligen door het verplicht voorschrijven van International Accounting Standards, gekoppeld aan een strakker toezicht, leiden naar onze mening tot een duidelijke voorkeur om het toezichthoudend orgaan op Europees niveau gestalte te geven. Wij bevelen de STE aan hiertoe het initiatief te nemen.

\section{Empirisch onderzoek}

\subsection{Ontwikkeling modeljaarrekening}

In 2.3 is aangegeven dat de tweede hoofdfase van het onderzoek bestond uit onderzoek onder analisten. Doel van dit onderzoek was het identificeren van die informatie-elementen welke voor stakeholders van belang zijn in het kader van hun besluitvorming. De term gebruikersgroepen is nauw verbonden met het begrip stakeholder, waarbij wordt verondersteld dat een gebruiker van financiële informatie hetzij tevens stakeholder is (bijvoorbeeld aandeelhouder of kredietverschaffer), hetzij de belangen van de stakeholder direct of indirect behartigt (financieel analist).

Om het benodigde inzicht te verkrijgen is gebruikgemaakt van verschillende onderzoeksmethoden. Allereerst is een aantal diepte-interviews gehouden met financieel analisten, om vast te stellen of zij gebruikmaken van jaarrekeninginformatie en zo ja, op welke wijze. De bevindingen uit deze interviews vormden aanleiding om de totaallijst met voorlopige informatie-elementen (3.2) te bewerken tot een document dat qua vorm en inhoud beter aansluit op de belevingswereld van analisten. Mede op basis van de input uit deze interviews is daarom gekozen voor de ontwikkeling van een modeljaarrekening. Dat wil zeggen dat de informatiebronnen die gebruikt zijn als input bij het uitgevoerde gebruikersonderzoek op een zodanige wijze zijn gestructureerd dat ze qua vorm, structuur en inhoud overeenkomen met de 'ideale' jaarrekening van een onderneming; vandaar de naam modeljaarrekening.

Naast de jaarrekening zijn ook informatie-elementen die betrekking hebben op het jaarverslag met behulp van de financieel analisten onderzocht.

\subsection{Uitvoering onderzoek onder analisten}

Met behulp van de modeljaarrekening heeft de selectie plaatsgevonden van de belangrijkste informatie-elementen. Daartoe is aan een geselecteerde groep van analisten de modeljaarrekening voorgelegd met de opdracht deze te analyseren op basis van het belang van alle daarin vermelde informatie-elementen. In het artikel van Blij in dit themanummer wordt hierop nader ingegaan.

Uit de totale set van 1812 voorlopige kwaliteitscriteria zijn uiteindelijk 583 informatie-elementen geselecteerd die naar de mening van de analisten in belangrijke mate bijdragen aan de kwaliteit van de externe verslaggeving. Hiervan hebben 487 informatie-elementen betrekking op de jaarrekening en 96 informatie-elementen op het jaarverslag. Al deze elementen zijn in het derde en laatste deel van het onderzoek gebruikt om de kwaliteit van de externe verslaggeving in Nederland te toetsen.

Voorts is gebleken dat met betrekking tot de keuze tussen alternatieve grondslagen voor waardering en resultaatbepaling een duidelijke voorkeur wordt uitgesproken voor onder andere de volgende alternatieven:

- verwerking van het cumulatief effect van stelselwijzigingen in het eigen vermogen (in plaats van in de winst- en verliesrekening);

- bij samengestelde (hybride) financiële instrumenten de componenten afzonderlijk classificeren onder het eigen vermogen en het vreemd vermogen (in plaats van niet afzonderlijk classificeren);

- effecten van verlengingen van de levensduur van materiële vaste activa verdelen over de resterende gebruiksduur (in plaats van direct ten gunste van de winst- en verliesrekening brengen);

- buiten gebruik gestelde materiële vaste activa niet herwaarderen naar hogere opbrengstwaarde (in plaats van wel herwaarderen en het verschil opnemen in een herwaarderingsreserve);

- bij overnames rekening houden met onlosmakelijk met de overname verbonden reorganisatiekosten (in plaats van het niet daarmee rekening houden);

- positieve goodwill activeren en afschrijven (in plaats van direct ten laste van het eigen vermogen boeken);

- joint ventures proportioneel consolideren (in plaats van waarderen tegen netto-vermogenswaarde);

- voorraden waarderen op basis van fifo-methode of gemiddelde kostprijs (in plaats van tegen de lifo-methode);

- incidentele posten van grote omvang altijd in de winst- en verliesrekening opnemen (en niet direct in het eigen vermogen muteren);

- altijd een latente belasting over herwaardering opnemen (in plaats van deze achterwege laten); 
- een voorziening assurantie eigen risico opnemen (in plaats van geen voorziening opnemen; deze voorkeur sluit niet aan bij de ontwikkelingen in de regelgeving);

- onder buitengewone baten en lasten incidentele posten opnemen, zoals reorganisatiekosten en boekwinsten bij verkoop van deelnemingen (in plaats van onder buitengewone baten en lasten uitsluitend posten opnemen die zelden voorkomen, zoals gevolgen van aardbevingen en kernrampen; deze voorkeur sluit niet aan op de internationale regelgeving);

- rente altijd als periodekosten in de winst- en verliesrekening opnemen (in plaats van activeren als onderdeel van de verkrijgingsprijs).

Daarnaast hebben de analisten zich uitgelaten over de afweging tussen enerzijds tijdigheid en betrouwbaarheid en anderzijds relevantie en betrouwbaarheid. Zij blijken een duidelijke prioriteit te geven aan de kwaliteitscriteria tijdigheid en relevantie en nemen daarbij bepaalde onzekerheden die de informatie minder betrouwbaar maken (zonder dat deze onbetrouwbaar wordt) op de koop toe.

\subsection{Onderzoek financiële verslaggeving}

Opzet

In de derde en laatste fase van het onderzoek heeft de uiteindelijke kwaliteitsmeting plaatsgevonden. Met behulp van de in het gebruikersonderzoek geïdentificeerde kwaliteitscriteria voor de jaarrekening en het jaarverslag zijn de financiële verslagen over $1999^{4}$ van de 60 grootste aan de AEX genoteerde ondernemingen geanalyseerd. Grootte is gemeten op basis van het criterium beurskapitalisatie en aandelenomzet. Als peildatum is gekozen 1 maart 2000. In het onderzoek zijn financiële instellingen (waaronder banken en verzekeringsmaatschappijen) buiten beschouwing gelaten De uiteindelijke lijst van de 60 ondernemingen die nader zijn onderzocht, blijkt uit tabel 2 (zie p. 413).

De resultaten zoals voor de ondernemingen weergegeven hebben uitsluitend betrekking op de analyse van de jaarrekeningen ${ }^{5}$. Ook de gepresenteerde eindscore aan het eind van deze paragraaf heeft slechts hierop betrekking. Dit sluit aan op de informatie-elementen zoals deze in de modeljaarrekening zijn opgenomen.

Ook de jaarverslagen (verslagen van de Raad van Bestuur) zijn geanalyseerd op basis van de informatie-elementen die in dat kader door analisten als belangrijk werden beschouwd. Toetsing van deze elementen is aanzienlijk complexer gebleken dan toetsing van de informatie-elemen- ten voor de jaarrekening. Dit werd vooral veroorzaakt doordat de informatie-elementen voor het jaarverslag een veel minder duidelijk gedefinieerde inhoud hadden dan die voor de jaarrekening. In dit artikel gaan wij slechts beknopt in op de analyse van de jaarverslagen.

De 487 geïdentificeerde informatie-elementen zijn in iedere onderzochte jaarrekening getoetst. Daarbij zijn drie mogelijke situaties onderscheiden:

1. Het informatie-element is van toepassing op de jaarrekening 1999 van de betreffende onderneming en wordt vermeld (code 1).

2. Het informatie-element is van toepassing op de jaarrekening 1999 van de betreffende onderneming en wordt niet vermeld (code 2).

3. Het informatie-element is niet van toepassing op de jaarrekening 1999 van de betreffende onderneming (code 3 ).

Voor iedere onderneming is op basis van dit onderzoek een drietal scores bepaald ${ }^{6}$ :

- De totaalscore: het aantal keren dat code 1 van toepassing is, met andere woorden dat het informatie-element in de jaarrekening is vermeld.

- De maximale score: het aantal keren dat code 1 of code 2 van toepassing is, met andere woorden dat het informatie-element van toepassing is.

- De eindscore: de totaalscore gedeeld door de maximale score.

De rangschikking van ondernemingen heeft plaatsgevonden op basis van de eindscores. De eindscore is een relatieve score, waarbij rekening is gehouden met de mate waarin informatieelementen wel of niet van toepassing zijn. Indien bijvoorbeeld een onderneming in het jaar 1999 geen acquisities heeft gepleegd, zijn de informatie-elementen met betrekking tot acquisities niet van toepassing. Daardoor kan een lagere totaalscore ontstaan dan voor de onderneming die wel acquisities heeft gepleegd en daarover wel enige informatie verschaft. De eindscore maakt daarom een betere vergelijking tussen verschillende soorten ondernemingen mogelijk.

Derhalve geldt: hoe hoger de eindscore, hoe beter aan de informatiebehoeften van de stakeholders is voldaan en hoe hoger de kwaliteit van de jaarrekening.

\section{Resultaten jaarrekening}

Alvorens in te gaan op de eindscores van de ondernemingen, presenteren wij voor alle ondernemingen gezamenlijk een overzicht van de gemiddelde eindscores op de verschillende jaarrekeningonderdelen (tabel 1, p. 412). In deze tabel 
Tabel 1: Gemiddelde scores voor de afzonderlijke jaarrekeningonderdelen

\begin{tabular}{|c|c|c|c|}
\hline Onderdeel & $\begin{array}{l}\text { Gemiddelde } \\
\text { eindscore (in \%) }\end{array}$ & $\begin{array}{l}\text { Aantal } \\
\text { informatie- } \\
\text { elementen }\end{array}$ & $\begin{array}{l}\text { Gemiddeld \% van } \\
\text { toepassing zijnde } \\
\text { informatie-elementen }\end{array}$ \\
\hline Voorraden & 96,30 & 6 & 76,67 \\
\hline Vlottende activa & 87,50 & 6 & 99,72 \\
\hline Gebeurtenissen na balansdatum & 85,42 & 4 & 31,67 \\
\hline Eigen vermogen & 78,53 & 56 & 58,33 \\
\hline Financiële vaste activa & 75,92 & 13 & 66,92 \\
\hline Materiële vaste activa & 75,06 & 20 & 71,67 \\
\hline Winst- en verliesrekening & 73,89 & 57 & 51,10 \\
\hline Schulden & 71,39 & 17 & 65,88 \\
\hline Stelselwijzigingen & 67,44 & 11 & 11,21 \\
\hline Vreemde valuta & 61,95 & 5 & 87,33 \\
\hline Winst per aandeel & 60,74 & 20 & 74,25 \\
\hline Voorzieningen & 58,60 & 20 & 53,92 \\
\hline Risico's samenhangend met financiële instrumenten & 51,16 & 2 & 71,67 \\
\hline Consolidatie & 51,02 & 10 & 68,00 \\
\hline Immateriële vaste activa & 50,51 & 19 & 49,21 \\
\hline Belastingen & 46,11 & 4 & 85,42 \\
\hline Overheidssubsidies & 41,67 & 4 & 4,58 \\
\hline Kasstroomoverzicht & 38,47 & 50 & 69,73 \\
\hline Afgeleide financiële instrumenten & 38,05 & 5 & 68,33 \\
\hline Meerjarenoverzicht & 37,31 & 50 & 86,33 \\
\hline Toelichting (overige elementen) & 37,07 & 18 & 79,91 \\
\hline Fusies, overnames en afstotingen & 27,16 & 43 & 63,12 \\
\hline Segmentatie & 23,62 & 44 & 73,52 \\
\hline Leasecontracten & 20,19 & 3 & 50,56 \\
\hline Totaal & 53,53 & 487 & \\
\hline
\end{tabular}

is eveneens het aantal getoetste informatie-elementen per onderdeel weergegeven en de mate waarin de informatie-elementen van toepassing bleken te zijn bij ondernemingen (de gemiddelde maximale score per onderwerp). De onderdelen zijn gerangschikt op basis van de gemiddelde eindscore ${ }^{7}$.

Uit tabel 1 blijkt dat de gemiddelde eindscore van alle informatie-elementen afgerond $54 \%$ bedraagt. Dit betekent dat gemiddeld slechts iets meer dan de helft van de in totaal 487 informatie-elementen die door analisten als belangrijk werden aangemerkt, in de onderzochte jaarrekeningen is vermeld.

De beste informatieverschaffing vindt plaats ten aanzien van het onderdeel Voorraden $(96,30 \%$ van alle gewenste informatie-elementen is vermeld), de slechtste op het gebied van leasecontracten $(20,19 \%$ van alle gewenste informatieelementen is vermeld).

Met betrekking tot het aantal informatie-elementen per onderdeel zijn vooral de onderdelen winst- en verliesrekening (57 elementen), eigen vermogen (56), het kasstroomoverzicht (50), het meerjarenoverzicht (50), segmentatie (44) en fusies, overnames en afstotingen (43) van belang. Opgemerkt wordt dat de indeling van informatieelementen in de verschillende categorieën soms subjectief is, namelijk indien het betreffende element aan verschillende onderdelen toerekenbaar is.

Het onderdeel dat gemiddeld het meest van toepassing is, betreft vlottende activa $(99,72 \%)$, terwijl het onderdeel overheidssubsidies het minst van toepassing is $(4,58 \%)$.

\section{Resultaten jaarverslagen}

Naast de jaarrekening is ook het jaarverslag getoetst aan de hand van de 96 informatie-elementen die door analisten als belangrijk werden aangeduid. Ook hier werden, evenals bij de jaarrekening, de scores bepaald van de afzonderlijke informatieelementen. De resultaten van de kwaliteitsanalyse van het jaarverslag zijn beduidend slechter dan die van de jaarrekening. Gemiddeld genomen voldoen de jaarverslagen slechts voor iets meer dan een 
kwart (26\%) aan de specifieke informatiebehoeften van de gebruikers. De hoogste score bedraagt $38 \%$, de laagste $15 \%$. Een derde van de elementen heeft een eindscore van $5 \%$ of lager, hetgeen wil zeggen dat maximaal $5 \%$ van de jaarverslagen deze informatie vermeldt. Deze lage scores geven aan dat het jaarverslag in zijn huidige vorm niet voldoet aan de informatiebehoeften van de gebruikers. Daarbij dient te worden opgemerkt dat een belangrijke oorzaak van de lage scores te wijten is aan het dikwijls kwalitatieve karakter van de verstrekte informatie. Met andere woorden, dikwijls wordt wel informatie betreffende de van belang zijnde elementen verschaft, maar is zij onvoldoende specifiek (kwantitatief). Ook hier is de conclusie alleszins gerechtvaardigd dat er veel ruimte voor verbetering is. Zoals reeds eerder aangegeven zijn de scores van het jaarverslag niet meegenomen in de rangschikking 8 .
Een punt waar niet specifiek in de score rekening mee is gehouden, maar dat wel van belang is, betreft de leesbaarheid en toegankelijkheid van de verstrekte informatie. Uit de analyse van de elementen is ook naar voren gekomen dat de informatie dikwijls moeilijk is te vinden en de onderlinge vergelijkbaarheid van jaarverslagen te wensen overlaat.

\section{Resultaten per onderneming}

Zoals aangegeven in 4.1 is de eindscore een relatieve score, bepaald op basis van de totale score van een onderneming, gedeeld door de maximale score. Bij de uiteindelijke bepaling van de rangorde zijn we tegen het probleem aangelopen dat een onderneming met weinig ingewikkelde verslaggevingsproblemen gemakkelijker een hoge score kan halen dan een onderneming met meer ingewikkelde problemen. Bijvoorbeeld, een onderne-

Tabel 2: Onderzochte ondernemingen, ingedeeld op basis van complexiteit van de verslaggeving

\begin{tabular}{|l|l|}
\hline Complexere verslaggeving & Minder complexe verslaggeving \\
\hline NV Koninklijke Nederlandse Petroleummaatschappij & IHC Caland \\
Wolters Kluwer & CSM \\
Philips Electronics & Nutreco Holding \\
DSM & Aalberts Industries \\
Buhrman & Laurus \\
Akzo Nobel & Océ \\
Hagemeyer & Vedior \\
Reed Elsevier & NBM-Amstelland \\
TNT Post Groep & Koninklijke Boskalis Westminister \\
VNU & GUCCI Group \\
Simac Techniek & Koninklijke Wessanen \\
Koninklijke KPN & Versatel Telecom International \\
Wegener & Holdingmaatschappij De Telegraaf \\
Stork & Randstad Holding \\
Vopak & United Pan-Europe Communications \\
Internatio-Müller & AND International Publishers \\
Vendex International & Heineken \\
Endemol Entertainment Holding & BE SemiConductor Industries \\
Koninklijke Ahold & EVC International \\
Getronics & CMG \\
Koninklijke Volker Wessels Stevin & Ordina \\
LCI Technology Group & ASM Lithograpy Holding \\
Koninklijke Numico & Toolex International \\
Koninklijke Nedlloyd & Landis Group \\
Koninklijke Luchtvaart Maatschappij & Unique International \\
Hollandsche Beton Groep & Exact Holding \\
ASM International & CSS Holding \\
Samas-Groep & Magnus Holding \\
Detron Group & Libertel \\
Hunter Douglas & TAS Groep \\
& \\
\hline
\end{tabular}

Noot: Op volgorde van de mate van complexiteit. 
ming die internationaal opereert (productie in meerdere landen), die bovendien in het verslagjaar 1999 actief is geweest op het overnamepad, en die ook immateriële vaste activa op haar balans heeft staan, heeft te maken met een groter aantal verslaggevingitems dan een onderneming die slechts nationaal opereert (produceert), geen overnames heeft gepleegd en geen immateriële vaste activa bezit.

Wij hebben daarom een verdeling gemaakt in twee groepen ondernemingen, op basis van een criterium dat door ons wordt aangeduid met 'complexiteit van de verslaggeving'. De mate van complexiteit wordt bepaald door de hoogte van de maximale score: hoe hoger, hoe complexer. De dertig ondernemingen met de hoogste maximale score zijn in de complexe groep ingedeeld, de overige dertig in de minder complexe groep.

Tabel 2 (p. 413) geeft een overzicht van alle ondernemingen die in het onderzoek zijn betrokken, ingedeeld naar de genoemde twee groepen, op volgorde van de mate van complexiteit.

In tabel 3 worden de beste tien ondernemingen van beide groepen vermeld.

Uit tabel 3 blijkt dat DSM de hoogste score heeft $(65,53 \%)$ van de ondernemingen met meer complexe verslaggeving en Libertel $(66,97 \%)$ van de ondernemingen met minder complexe verslaggeving. Van die twee heeft Libertel dus de hoogste eindscore. Deze beide ondernemingen hebben tijdens het symposium op 23 november 2000 (zoals vermeld in paragraaf 1) uit handen van minister Zalm de prijs gekregen voor het beste financiële verslag van $1999^{9}$.

\section{Conclusies en aanbevelingen}

\section{Conclusies uit empirisch onderzoek}

In dit artikel is beknopt verslag gedaan van de resultaten van het onderzoek naar de kwaliteit van de externe financiële verslaggeving in Nederland. Een algemene conclusie die in het kader van de probleemstelling kan worden getrokken, is dat gemiddeld 54\% van de door financieel analisten gewenste informatie-elementen in de jaarrekening door de ondernemingen is verstrekt. Deze score sluit aan bij de 'kleine zes' die Traas eerder heeft genoemd (zie paragraaf 1). Dit betekent dat er nog veel ruimte is voor verbetering van de kwaliteit. Onderdelen die in de jaarrekening van belang worden geacht en relatief slecht scoren, zijn het kasstroomoverzicht (38\%), meerjarenoverzicht (37\%), fusies, overnames en afstotingen (27\%), segmentatie (24\%) en leasecontracten (20\%).

Behalve de jaarrekening is ook het jaarverslag getoetst aan de hand van de 96 informatie-elementen die door analisten als belangrijk werden aangeduid. Algemeen kan worden gesteld dat de scores voor informatie-elementen met betrekking tot het jaarverslag lager uitvallen dan de jaarrekening. Gemiddeld genomen voldoen de zestig ondernemingen voor $26 \%$ aan de door analisten als belangrijk aangeduide informatie.

Verbetering van de kwaliteit kan uiteraard geschieden door meer informatie-elementen op te nemen die door analisten zijn gewenst. Uit het empirisch onderzoek hebben wij in dit verband acht concrete aanbevelingen afgeleid, die in de bijlage zijn opgenomen (aanbevelingen 1 tot en met 8). Ook bevelen wij ondernemingen in algemene zin aan een hoge kwaliteit van de financiële

Tabel 3: Overzicht top-10 kwalitatief beste jaarrekening 1999, opgesplitst aan de hand van het criterium complexiteit

\begin{tabular}{|l|c|l|c|}
\hline Complexere verslaggeving & $\begin{array}{l}\text { Totaalscore } \\
\text { Jaarrekening } \\
\text { (in \%) }\end{array}$ & Minder complexe verslaggeving & $\begin{array}{l}\text { Totaalscore } \\
\text { Jaarrekening } \\
\text { (in \%) }\end{array}$ \\
\hline DSM & 65,53 & Libertel & 66,97 \\
Koninklijke Ahold & 61,32 & Oce & 63,49 \\
Akzo Nobel & 61,29 & ASM Lithography Holding & 61,22 \\
Buhrman & 61,25 & Gucci Group & 60,33 \\
Koninklijke Nedlloyd & 61,03 & IHC Caland & 60,19 \\
Philips Electronics & 60,99 & United Pan-Europe Communications & 57,84 \\
Koninklijke Luchtvaart Maatschappij & 58,01 & CMG & 56,93 \\
VNU & 57,97 & Koninklijke Wessanen & 55,45 \\
Koninklijke Volker Wessels Stevin & 57,65 & BE Semiconductor Industries & 55,23 \\
Vopak & 55,40 & EVC International & 54,21 \\
\hline
\end{tabular}


verslaggeving met woord en daad te belijden (aanbeveling 9).

\section{Verbeteringen in infrastructuur}

Voorts is verbetering van de kwaliteit mogelijk door verbetering van de infrastructuur. Dit betreft in het bijzonder de regelgeving en het toezicht. Daaromtrent hebben wij elf aanbevelingen geformuleerd, die in de bijlage zijn opgenomen en nader zijn toegelicht. Op de ontwikkelingen in regelgeving gaan wij hieronder nader in. In het artikel van Vergoossen in dit themanummer worden de ontwikkelingen in het toezicht besproken. De regelgeving in Nederland wordt in het algemeen gekenmerkt door:

- redelijk globale wettelijke bepalingen en meer gedetailleerde bepalingen van niet-wettelijke aard (de Richtlijnen voor de Jaarverslaggeving van de Raad voor de Jaarverslaggeving, RJ);

- geen directe afdwingbaarheid van de genoemde Richtlijnen;

- geen vermelding in de jaarrekening van afwijkingen van Richtlijnen; en

- totstandkoming van Richtlijnen op basis van een consensus tussen drie partijen (verschaffers, gebruikers en controleurs), met als gevaar dat geen directe aansluiting bestaat op de informatiebehoeften van stakeholders; de consensus leidt er vaak toe dat meerdere opties worden opengelaten.

Dit leidt ertoe dat sprake is van een zeer grote mate van vrijheid bij de inrichting van de jaarrekening. Bij internationale onderzoeken van vergelijkingen tussen verslaggevingsculturen is Nederland veelal een 'sui generis', een soort op zichzelf, gekenmerkt door een grote mate van 'professional judgment' (zie bijvoorbeeld Nobes and Parker, 1998). In de woorden van Heijnen (1996): 'een paradijs van vrijblijvendheid'.

De infrastructuur in Nederland ondergaat op dit moment reeds belangrijke veranderingen en dit zal in de nabije toekomst nog veel sterker worden. Oorzaak daarvan is de internationale harmonisatie. De algemene opvatting is inmiddels dat Nederland niet langer een sui generis kan zijn en dat aanpassing van de eigen regels aan de internationale opvattingen een noodzaak is. In dat verband is de RJ vanaf ongeveer 1995 begonnen met het zoveel mogelijk integraal opnemen van de International Accounting Standards (IAS) van het International Accounting Standards Committee (IASC) als Nederlandse Richtlijnen voor de Jaarverslaggeving. Dit heeft al geleid tot een vermindering van het aantal opties voor waar- dering en resultaatbepaling en tot een sterke uitbreiding van het aantal verplicht te verstrekken informatie-elementen. Daarmee neemt ook de vergelijkbaarheid toe. Niettemin blijft de situatie bestaan dat de Richtlijnen niet wettelijk afdwingbaar zijn en dat geen vermelding van afwijkingen in de jaarrekening plaatsvindt.

Een verdergaande ontwikkeling is daarom het voornemen van de Europese Commissie om uiterlijk vanaf 2005 toepassing van IAS in de geconsolideerde jaarrekening voor alle Europese beursgenoteerde ondernemingen verplicht te stellen. Het Nederlandse kabinet heeft hierop inmiddels met enthousiasme gereageerd, en wenst het toepassingsgebied in elk geval uit te breiden tot dat van de niet-beursgenoteerde financiële instellingen. Toepassing van IAS betekent dat alle vergaande bepalingen van IAS zonder uitzondering dienen te worden nageleefd ${ }^{10}$. IAS wordt wettelijk afdwingbaar en afwijkingen zijn in feite niet mogelijk. Wij zijn van mening dat toepassing van IAS leidt tot een verbetering van de kwaliteit van de financiële verslaggeving in Nederland, vooral omdat hierdoor een betere vergelijkbaarheid ontstaat en daardoor een betere financiële analyse mogelijk is. Het is om die reden wenselijk dat Nederlandse beursgenoteerde ondernemingen reeds voor 2005 IAS toepassen.

Voor de meeste niet-beursgenoteerde ondernemingen zullen ook na 2005 de Nederlandse Richtlijnen blijven gelden. Uiteraard geldt ook voor die ondernemingen dat de kwaliteit van de verslaggeving een relevant vraagstuk is. Naar onze mening dient dat te leiden tot een aanpassing van de Nederlandse verslaggevingscultuur. Wij bepleiten in eerste instantie dat ook niet-beursgenoteerde grote ondernemingen zoveel mogelijk wordt aanbevolen IAS toe te passen. Voor middelgrote en kleine ondernemingen zouden naar onze mening de Richtlijnen van de RJ de leidraad dienen te zijn, met die kanttekening dat deze zoveel mogelijk gebaseerd dienen te zijn op IAS (met afwijkingen en opties waar dit gezien de aard en omvang van de ondernemingen doelmatig is) en dat de Richtlijnen wettelijk verankerd zouden moeten worden (dan wel anderszins afdwingbaar). Afwijkingen van Richtlijnen zonder dat hiervoor gegronde redenen bestaan en zonder dat dit blijkt uit de jaarrekening, moeten in de toekomst niet meer mogelijk worden geacht.

\section{Slotbeschouwing}

Dit onderzoek is als zodanig een eenmalige exercitie. Het Limperg Instituut heeft niet het voornemen een dergelijk onderzoek jaarlijks te 
actualiseren, al betekent dit uiteraard niet dat de kwaliteitscriteria alleen voor 1999 relevantie zouden hebben. Wat betreft het aspect van de beste financiële verslaggeving in Nederland bestaat al sinds 1953 de Henri Sijthoff-prijs. Deze prijs heeft een belangrijke stimulans gegeven aan de verbetering van de kwaliteit van de financiële verslaggeving. Een duidelijk verschil tussen dit onderzoek en de Henri Sijthoff-prijs is dat de criteria voor toetsing in dit onderzoek explicieter zijn en dat daarmee de transparantie groter is. Wij pleiten in aanbeveling 20 daarom voor meer transparantie in de wijze waarop de prijstoekenning plaatsvindt. Wij spreken daarbij de wens uit dat de Henri Sijthoff-prijs nog lange tijd haar bijdrage mag leveren aan de verbetering van de kwaliteit van de financiële verslaggeving in Nederland.

\section{ITERAT U U R}

American Institute of Certified Public Accountants, (1994), Improving Business Reporting - a customer focus; meeting the information needs of investors \& creditors.

Canadian Institute of Chartered Accountants, (1991), Information to be Included in the Annual report to Shareholders.

Center for International Financial Analysis and Research, (1989, 1993), International Accounting and Auditing Trends.

Heijnen, H.M., (1996), De Ondernemingskamer en de handhaving van het jaarrekeningenrecht; in: 25 jaar Ondernemingskamer. De betekenis van de OK voor ondernemend Nederland.

Institute of Chartered Accountants of England and Wales, (1975), The Corporate Report.

Institute of Chartered Accountants of England and Wales, (1991), The Future Shape of Financial Reports.

Institute of Chartered Accountants of Scotland, (1988), Making Corporate Reports Valuable.

Jonas, G. J. en Jeannot Blanchet, (2000), Assessing Quality of Financial Reporting, Accounting Horizons, september, pp. 353-363.

Kuijck, J.R.H.J., (1999), De strijd tegen creative accounting, in: Fiducie, oktober, pp. 25-28.

Levitt, A., (1998), The Numbers Game, Speech at the NYU Center for Law and Business New York.

Limperg Instituut, (2000), Kwaliteit van externe financiële verslaggeving in Nederland, Brochure bij symposium 23 november 2000 Universiteit van Amsterdam.

Nobes, C. en R.H. Parker, (1998), Comparative International Accounting, fifth edition, Prentice Hall.

Smith, T., (1992), Accounting for Growth, Stripping the Camouflage from Company Accounts, Century
Business.

Traas, L., (1999), Om de kwaliteit van de Nederlandse jaarverslaggeving, in: Management Control en Accounting, nr. 2, pp. 22-30, en nr. 3, pp. 30-39.

Volten, H., (1992) , Accountants en Accountancy Internationale Trends, in: De Accountant, juni, pp. 594-595.

Zeff, S., F. van der Wel en C. Camfferman, (1992), Company Financial Reporting, a historical and comparative study of the Dutch regulatory process, North Holland.

\section{NOTEN}

1 Levitt (1998); zie voor een overzicht onder andere Van Kuijck (1999) en Traas (1999).

2 Dit rapport handelt over de effectiviteit van audit committees en stelt in dat verband onder andere dat de externe accountant met het audit committee niet slechts over de aanvaardbaarheid van de jaarrekening dient te overleggen, maar de kwaliteit van de jaarrekening ('the quality of financial reporting') ter discussie dient te stellen.

3 Het projectteam 'Kwaliteit van de externe financiële verslaggeving in Nederland' bestond uit Prof. Dr. M.N. Hoogendoorn, Prof. Dr. G.M.H. Mertens, Drs. I.H.C. Blij, Drs. M. Pronk en Drs. M.T. van den Einde. Andere onderzoekers van onderdelen van het project waren Dr. R.J.M. Beeres, Dr. G.J.M. Braam, Prof. Dr. J. Dijksma, Drs. M.G. Eggenkamp, Drs. E.H. Kelder, Prof. Dr. H.P.A.J. Langendijk, Drs. E. Louwrier, C. Regoort, Drs. J.G. van Rooijen en Drs. S.G. Room. Regelmatig overleg en afstemming heeft plaatsgevonden met een stuurgroep, bestaande uit Drs. K. Kruisbrink (Voorzitter), Drs. H. Haarbosch, Prof. Dr. J. van Helleman (opvolger van H. Franse), Prof. Dr. P.G.W. Jansen, Mr. E.D.G. Kiersch (opvolger van Mr. S. Wortmann), Prof. W.P. Moleveld, P.A.M. Sampers en Prof. Dr. R.G.A. Vergoossen.

$4 \mathrm{Bij}$ gebroken boekjaren is de jaarrekening onderzocht waarvan het grootste aantal maanden in 1999 viel. Bij een balansdatum 31 maart is dat de jaarrekening 1999/2000, bij een balansdatum 30 november de jaarrekening 1998/1999.

5 Hierbij past wel de opmerking dat, indien een informatie-element met betrekking tot de jaarrekening niet in de jaarrekening is opgenomen maar in het jaarverslag, dit element wel als 'vermeld' wordt aangemerkt. Dit doet zich bijvoorbeeld voor bij bepaalde segmentinformatie.

$6 \mathrm{Bij}$ het bepalen van de eindscore is geen verdere weging opgenomen van een mogelijk verschil in belang tussen de informatie-elementen onderling. Evenmin is er rekening gehouden met een verschil in belangrijkheid van de categorieën waartoe een informatie-element behoort, zoals aangegeven in 3.3. 
Wel zijn gevoeligheidstesten uitgevoerd door toekenning van verschillende wegingsfactoren. Voor de rangschikking van de beste ondernemingen leidt dat echter niet tot wezenlijk andere eindscores.

7 Met betrekking tot het onderdeel 'niet in de balans opgenomen verplichtingen' zijn door analisten geen belangrijke informatie-elementen geïdentificeerd.

8 De toevoeging van de jaarverslagscores aan de jaarrekeningscores brengt overigens geen wezenlijke veranderingen teweeg in de rangschikking van de topposities. In het eindrapport zullen beide scores afzonderlijk per onderneming worden weergegeven.

9 In de brochure bij dit symposium en in het eindrapport zijn uitgebreide juryrapporten opgenomen.

$10 \mathrm{Er}$ is in zeer uitzonderlijke gevallen een afwijking mogelijk ('true and fair override', derogatie), maar de verwachting is dat dit een dode letter zal zijn; mocht toch worden afgeweken dan is een gegronde onderbouwing daarvan plus een uitgebreide vermelding van aard en effecten in de toelichting vereist.

\title{
Bijlage: 20 aanbevelingen bij onderzoek kwaliteit financiële verslaggeving in Nederland
}

\begin{abstract}
Aanbevelingen die voortkomen uit het empirisch onderzoek
1. Ondernemingen wordt aanbevolen meer relevante informatie in hun financieel verslag op te nemen. Uit het onderzoek blijkt dat, om te kunnen voldoen aan de wensen van de gebruikers, de kwaliteit van de financiële verslaggeving in belangrijke mate dient te worden verbeterd.
\end{abstract}

Toelichting: Financieel analisten geven aan dat het financiële verslag als de belangrijkste indirecte bron van informatie wordt beschouwd. De informatie-elementen die analisten van belang vinden voor een kwalitatief goede verslaggeving, worden in veel gevallen niet in de jaarrekening aangetroffen. Gemiddeld verschaffen de onderzochte ondernemingen slechts iets meer dan de helft (54\%) van deze informatie-elementen.

2. Ondernemingen wordt aanbevolen stelselwijzigingen die niet door regelgeving worden afgedwongen slechts bij uitzondering door te voeren. Voor alle stelselwijzigingen geldt dat deze met terugwerkende kracht zouden moeten worden doorgevoerd en dat vergelijkende cijfers, ook in meerjarenoverzichten, worden aangepast. Het cumulatief effect van een stelselwijziging dient daarbij in het eigen vermogen te worden verwerkt.

Toelichting: Financieel analisten vinden vergelijkbaarheid in de tijd voor hun analyse van groot belang. Stelselwijzigingen verstoren deze vergelijkbaarheid en bemoeilijken daarmee de financiële analyse. Daarom wordt aanbevolen het vrijwillig doorvoeren van stelselwijzigingen tot een minimum te beperken en hiertoe alleen over te gaan als sprake is van evidente verhoging van de kwaliteit van de verslaggeving. Doorgevoerde stelselwijzigingen dienen uitgebreid en adequaat te worden toegelicht en alle vergelijkende cijfers dienen te worden aangepast. Analisten geven daarbij een duidelijke voorkeur voor verwerking van het cumulatief effect via het eigen vermogen. Op deze wijze is het mogelijk goede financiële analyses te blijven uitvoeren.

3. Ondernemingen wordt aanbevolen de informatieverstrekking met betrekking tot fusies, overnames en afstotingen te verbeteren.

Toelichting: Fusie- en overnameactiviteiten hebben de laatste jaren een hoge vlucht genomen, waardoor de aard van de activiteiten van veel ondernemingen ingrijpend gewijzigd is. De volgtijdige vergelijkbaarheid heeft hieronder sterk geleden. Uit het empirisch onderzoek blijkt dat informatie met betrekking tot fusies, overnames en afstotingen vaak te wensen overlaat. In het algemeen wordt informatie verlangd met betrekking tot in elk geval de overnameprijs, de betaalde goodwill en de verwachte gevolgen van overnames en afstotingen voor omzet, bedrijfsresultaat, nettowinst en activa en passiva.

4. Ondernemingen wordt aanbevolen meer gesegmenteerde informatie te verstrekken en daarbij de wijze waarop segmentatie plaatsvindt zoveel mogelijk constant te houden. Indien toch wijzigingen worden doorgevoerd in de indeling van segmenten, is het wenselijk daarop een duidelijke toelichting te geven en waar mogelijk vergelijkende cijfers aan te passen.

Toelichting: Gesegmenteerde informatieverstrekking is één van de belangrijkste informatieonderdelen voor de financieel analist. Uiteraard dienen ten minste het bedrijfsresultaat, de activa en de investeringen per bedrijfs- en geografisch segment te worden verstrekt. Daarnaast ontbreekt bijvoorbeeld vaak een segmentatie van de kasstromen en een segmentatie naar valuta. Omwille van het inzicht in de afzonderlijke bedrijfsactiviteiten en de daaruit voortvloeiende financiële resultaten is het voorts van belang een consistent beeld te presenteren. 
5. Ondernemingen wordt aanbevolen een overzicht van kwartaalcijfers in de jaarrekening op te nemen.

Toelichting: De jaarrekening is mede te beschouwen als een samenvatting van de kwartaalrapportages. De opbouw van de jaarcijfers uit de kwartaalcijfers geeft een samenvattend overzicht van de effecten van kwartaalinvloeden op de cijfers, hetgeen kan bijdrage aan de financiële analyse.

6. Ondernemingen wordt aanbevolen uitgebreide meerjarenoverzichten over relatief langere perioden op te stellen.

Toelichting: Meerjarenoverzichten bieden bij uitstek de mogelijkheid van een historische analyse. Een volledige balans en winsten verliesrekening, aangevuld met kerncijfers, over ten minste vijf jaar, maar bij voorkeur tien jaar, sluit daarbij het beste aan.

7. Ondernemingen wordt aanbevolen het jaarverslag zo toegankelijk en leesbaar mogelijk op te zetten, teneinde de onderlinge vergelijkbaarheid tussen jaarverslagen te verbeteren. Het is wenselijk dat initiatieven worden genomen voor de ontwikkeling van een standaardindeling van het jaarverslag.

Toelichting: De informatie in het jaarverslag is voor financieel analisten van groot belang. De toegankelijkheid en vergelijkbaarheid laten vaak te wensen over. Hoewel uiteraard iedere onderneming uniek is, kan overwogen worden een basisindeling te ontwerpen waardoor de toegankelijkheid wordt vergroot (vergelijkbaar met de standaardindeling voor een jaarrekening).

8. Ondernemingen wordt aanbevolen in het jaarverslag meer kwantitatieve informatie op te nemen met betrekking tot toekomstige ontwikkelingen en om in het daarop volgende jaarverslag de werkelijke ontwikkelingen met de verwachtingen te vergelijken.

Toelichting: Kwantificering van toekomstverwachtingen draagt bij aan de goede oordeelsvorming van analisten. Daarbij is het niet noodzakelijk exacte winstvoorspellingen te geven, maar wel dat tenminste een gevoeligheidsanalyse wordt verstrekt van beïnvloedende factoren. Voorts vereist een adequate verantwoording dat eerder uitgesproken verwachtingen worden geplaatst tegenover de in een boekjaar gerealiseerde ontwikkelingen.

\section{Overige aanbevelingen}

De navolgende aanbevelingen hebben betrekking op de algemene beschouwingen die in het eindrapport aan de orde komen. Zij zijn niet op enigerlei wijze getoetst. Het doel van deze aanbevelingen is om discussie over deze onderwerpen te stimuleren.

Algemeen

9. Ondernemingen wordt aanbevolen een hoge kwaliteit van de financiële verslaggeving met woord en daad te belijden.

Toelichting: Kwaliteit is gericht op een optimale communicatie met stakeholders. In het kader van de financiële verslaggeving zijn dat vooral aandeelhouders en vreemdvermogenverschaffers. Het belijden van concepten als vergroting van de aandeelhouderswaarde ('shareholder value') en verbetering van de corporate governance kan alleen maar serieus worden genomen als dit samengaat met een verbetering van de kwaliteit in de financiële verslaggeving.

Regelgeving

10. Het is wenselijk dat Nederlandse beursgenoteerde ondernemingen reeds voor 2005 International Accounting Standards integraal toepassen.

Toelichting: Toepassing van International Accounting Standards (IAS) leidt tot een verbetering van de kwaliteit van de financiële verslaggeving, vooral omdat hierdoor een betere vergelijkbaarheid ontstaat en daardoor een betere financiële analyse mogelijk is. Verwacht mag worden dat toepassing van IAS vanaf uiterlijk 2005 verplicht wordt. Het Nederlandse bedrijfsleven zou daarop niet moeten willen wachten, maar zelf het voortouw moeten nemen in het tijdig toepassen van IAS, waarbij eventuele wettelijke belemmeringen door de wetgever moeten worden weggenomen.

11. Ook niet-beursgenoteerde grote ondernemingen wordt aanbevolen International Accounting Standards toe te passen. Voor middelgrote en kleine ondernemingen is het van belang dat de Richtlijnen voor de Jaarverslaggeving (opgesteld 
door de Raad voor de Jaarverslaggeving) van kracht blijven. Deze zouden wettelijk verankerd moeten worden. Voorts zouden zij zoveel mogelijk gebaseerd moeten zijn op IAS.

Toelichting: Vaststellende dat IAS de internationale norm voor kwalitatief goede verslaggeving is, zou dit ook voor de grote, economisch belangrijke, niet-beursgenoteerde ondernemingen de leidraad moeten zijn. Voor middelgrote en kleine ondernemingen gaat volledige toepassing van IAS te ver. Voor deze ondernemingen zou toepassing van de Richtlijnen voor de Jaarverslaggeving verplicht moeten zijn. Die Richtlijnen zouden dan gebaseerd moeten zijn op IAS en vooral moeten bestaan uit het geven van vrijstellingen van de verstrekking van informatie-elementen (gebaseerd op de gebruikersgroepen van de ondernemingen) en uit interpretaties en toepassingen voor niet door IAS geregelde situaties en organisaties.

In uitzonderingsgevallen kan de mogelijkheid worden geboden tot vereenvoudigde grondslagen van waardering en resultaatbepaling. De formele status van de Richtlijnen is op dit moment beperkt. Dit biedt de mogelijkheid van de Richtlijnen af te wijken, zonder dat hiervoor gegronde redenen bestaan en zonder dat de afwijking uit de jaarrekening blijkt. Dit is een onwenselijke situatie. Daarom is een wettelijke verankering gewenst.

Accountantscontrole en toezicht

12. De controlerend accountant heeft een belangrijke functie in het bewaken van de kwaliteit van de financiële verslaggeving. Aanbevolen wordt mogelijke verbeteringen in de kwaliteit te rapporteren aan het toezichthoudend orgaan van de rapporterende vennootschap.

Toelichting: De controlerend accountant speelt een primaire rol in de handhaving van de kwaliteit van de financiële verslaggeving. Deze rol zou verder moeten gaan dan uitsluitend vaststellen dat de geldende wet- en regelgeving is nageleefd, aangezien ook met een gedetailleerde en stringente wet- en regelgeving de mogelijkheid van ongewenste beïnvloeding van cijfers kan blijven bestaan. Mogelijke verbeteringen in de kwaliteit zou de accountant moeten rapporteren aan het toezichthoudend orgaan (Raad van Commissarissen, audit committee).

13. Het is wenselijk een orgaan op te zetten dat specifiek belast is met het toezicht op de financiële verslaggeving, naar het voorbeeld van het Financial Reporting Review Panel in het Verenigd Koninkrijk.

Toelichting: De kwaliteit van financiële verslaggeving wordt mede bepaald door de mate waarin toezicht daarop wordt uitgeoefend. De Ondernemingskamer (OK) in Nederland is hiervoor niet geschikt, aangezien de OK niet zelfstandig actie mag ondernemen en een hoge toegangsdrempel voor klagers kent. Bovendien duren de procedures gemiddeld erg lang. Een efficiënter en actiever toezichtsmechanisme is daarom gewenst. Het Britse Financial Reporting Review Panel kan hierbij als voorbeeld dienen. Dit panel is laagdrempelig en voornamelijk reactief. Een stap verder kan zijn door het toezichtsorgaan ook zelf actief te laten optreden. Hoewel het denkbaar is een dergelijk toezichthoudend orgaan in Nederland op te zetten, lijkt het wenselijker de Europese krachten op dit punt te bundelen. De STE zou daarvoor het initiatief kunnen nemen ${ }^{1}$.

14. Bij wisseling van controlerend accountant dient de voorgaande accountant de mogelijkheid te krijgen meningsverschillen inzake de inhoud van de jaarrekening toe te lichten bij het orgaan dat belast is met het toezicht op de financiële verslaggeving.

Toelichting: De bewaking van de kwaliteit van de financiële verslaggeving door de controlerend accountant mag niet worden aangetast doordat deze door de vennootschap kan worden vervangen door een andere accountant. Daartoe moet de vervangen accountant de mogelijkheid hebben meningsverschillen met de ondernemingsleiding inzake de inhoud van de jaarrekening (over grondslagen van waardering en resultaatbepaling of over de in de toelichting op te nemen informatie) toe te lichten bij het toezichthoudend orgaan als genoemd in aanbeveling 13. Dit kan voor het orgaan aanleiding zijn voor nader onderzoek.

\section{Financiele analyse}

15. Ten behoeve van het voortdurend aanpassen van kwaliteitscriteria aan gewijzigde inzichten is het wenselijk een panel van financieel analisten in te stellen².

Toelichting: Omdat de kwaliteit van financiële verslaggeving bepaald wordt door de mate waarin aan de informatiebehoeften van stakeholders wordt voldaan, is een regelmatige communicatie met stakeholders van belang. Financieel analisten vormen het professionele intermediair waarmee deze communicatie het beste kan worden aangegaan. Dit kan leiden tot 
aanpassingen in de regelgeving, zowel in de zin dat informatie-elementen worden toegevoegd als dat minder belangrijke informatie-elementen worden geschrapt. Het panel kan een orgaan zijn van de Raad voor de Jaarverslaggeving.

16. Financiële pers en wetenschappers worden gestimuleerd met grotere regelmaat kritische beoordelingen van jaarrekeningen uit te voeren.

Toelichting: Een kritische financiële pers en kritische wetenschappers zijn belangrijke factoren in de handhaving van kwalitatief goede verslaggeving.

17. Voor financiële analisten is een permanente educatie op het gebied van financiële verslaggeving van groot belang. Nader onderzoek naar de kwaliteit van financiële analyses is wenselijk.

Toelichting: Financiële analyse door analisten van externe financiële verslaggevinginformatie draagt in belangrijke mate bij aan een goed functionerende kapitaalmarkt. De dynamiek en complexiteit van externe verslaggeving vereist een grote mate van deskundigheid, zowel wat inhoud als analytisch vermogen betreft. Daartoe is permanente educatie wezenlijk. Het is niet duidelijk wat de kwaliteit is van de huidige financiële analyse in Nederland. Een nader onderzoek daarnaar is wenselijk.

\section{Tussentijdse berichtgeving en berichtgeving op internet}

18. Het is wenselijk de frequentie van tussentijdse berichtgeving door beursgenoteerde ondernemingen te verhogen.

Toelichting: Eén van de aspecten van kwalitatief goede verslaggeving is de tijdigheid van rapportering. Voor beursgenoteerde ondernemingen zou dit moeten leiden tot rapportages per kwartaal, die sneller dan tot nu toe gebruikelijk worden bekend gemaakt.

19. Beursgenoteerde ondernemingen wordt aanbevolen financiële verslaggeving op internet te verbeteren door meer informatie te verstrekken die de mogelijkheid tot analyse van financiële gegevens vergroot.

Toelichting: Het op internet plaatsen van het integrale financiële verslag (waaronder de jaarrekening), de tussentijdse berichten en de persberichten is een minimale eis. Daarnaast wordt aanbevolen gegevens ter beschikking te stellen die een verbetering van de financiële analyse mogelijk maken. Daarbij kan gedacht worden aan het beschikbaar stellen van historische reeksen, maandgegevens, segmentgegevens, en alternatieve opstellingsmogelijkheden (omzetting in andere talen, omzetting op basis van alternatieve grondslagen van waardering en resultaatbepaling). Toepassing van XBRL (eXtended Business Reporting Language) door ondernemingen kan hieraan een belangrijke bijdrage leveren.

Henri Sijthoff-prijs

20. Het is wenselijk dat de transparantie inzake de toekenning van de Henri Sijthoff-prijs wordt verbeterd.

Toelichting: Eén van de uitkomsten van dit onderzoek is dat een prijs is verleend aan het beste financiële verslag van Nederlandse ondernemingen. De criteria voor toekenning zijn gebaseerd op wetenschappelijk onderzoek onder financieel analisten. De mate waarin jaarrekeningen wel of niet aan criteria voldoen, wordt per criterium inzichtelijk gemaakt. In Nederland bestaat al lange tijd de Henri Sijthoff-prijs voor de beste financiële verslaggeving. Deze prijs is een belangrijke stimulans voor de verbetering van de kwaliteit van de verslaggeving. Niet duidelijk is echter hoe de specifieke criteria voor de beoordeling van de financiële verslaggeving van jaar tot jaar worden vastgesteld en hoe deze criteria bij de beoordeling van financiële verslagen van ondernemingen zijn toegepast. Het is wenselijk financieel analisten in te schakelen bij de jaarlijkse herijking van kwaliteitscriteria (bijvoorbeeld via het panel van financieel analisten zoals genoemd in punt 15) en volledig transparant te zijn in de toetsing en weging van deze criteria. Er is geen behoefte aan twee prijzen die hetzelfde doel dienen. De Henri Sijthoff-prijs kan, indien op moderne en transparante leest geschoeid, nog vele jaren mee.

NOTEN

1 Deze aanbeveling is geformuleerd tijdens het symposium op 23 november 2000 . Wij constateren dat inmiddels het ministerie van Financiën door middel van een consultatienota de eerste initiatieven hiertoe heeft ondernomen.

2 In de aanbeveling die in de brochure van het Limperg Instituut is geformuleerd, hebben wij hieraan toegevoegd dat dit panel een orgaan kan zijn van de STE of van een gezamenlijke Europese beurstoezichthouder. Bij nader inzien is dit een minder goed idee, aangezien een toezichthoudend orgaan niet tevens criteria of regels moet vaststellen. Het orgaan kan daarom beter gekoppeld zijn aan bijvoorbeeld de Raad voor de Jaarverslaggeving. 